\title{
Optimal Cropping Sequence in Pluriactive Non-specialised Vegetable Farms in the Northwest Region of Cameroon
}

\author{
Godlove Shu ${ }^{1,3}$, *, Jules René Minkoua Nzie ${ }^{2}$, Ernest L. Molua ${ }^{1,3}$ \\ ${ }^{1}$ Department of Agricultural Economics and Agribusiness, Faculty of Agriculture and Veterinary Medicine, University of Buea, Buea, \\ Cameroon \\ ${ }^{2}$ Department of Economics, Faculty of Social and Management Science, University of Buea, Buea, Cameroon \\ ${ }^{3}$ Centre for Independent Development Research, Buea, Cameroon
}

Email address:

Shugodlove58@yahoo.com (G. Shu)

${ }^{*}$ Corresponding author

\section{To cite this article:}

Godlove Shu, Jules René Minkoua Nzie, Ernest L. Molua. Optimal Cropping Sequence in Pluriactive Non-specialised Vegetable Farms in the Northwest Region of Cameroon. International Journal of Agricultural Economics. Vol. 3, No. 5, 2018, pp. 112-117.

doi: $10.11648 /$ j.ijae.20180305.13

Received: May 26, 2018; Accepted: October 4, 2018; Published: October 29, 2018

\begin{abstract}
Cameroon champions the vegetable subsector in the Central African sub region both in output levels, export quantities and foreign exchange earnings. The country exports, formally and informally, fresh vegetables to neighboring countries like Nigeria, Central African Republic, Gabon and Equatorial Guinea. Besides ensuring food self-sufficiency, the primary intention of these pluriactive non-specialized vegetable farmers who also cultivate staple energy food crops as complementary and supplementary enterprises is to maximize farm profits subject to the numerous constraints. These constraints are further compounded by an acute incidence of climate variability, seasonal price fluctuations and poor farm planning. This study sought to find out an annual cropping pattern or sequence that maximizes annual returns and enhances the optimal allocation and utilization of farm resources. The study adopted the stratified random sampling technique to interview 120 vegetable farmers in the Northwest Region of Cameroon, from which pluriactive non-specialized were identified. This data was subjected to inferential statistical and dynamic programming analytical techniques. Theresults identified sixteen species of vegetable crops cultivated alongside energy food crops in the study area. The study further identified three cropping seasons in a year (March-June, July-October, and November-February) and suggested the prioritization of the tuber vegetable during the first cropping season, the leafy vegetables during the second cropping season and the fruit vegetables during the third cropping season. This optimal cropping pastern is highly responsive to climate weather risks and market shocks thus presenting potentials of yielding higher profits of up to 5256614.8 FCFA ((US\$ 8761.0) per annum from pluriactive vegetable farming.
\end{abstract}

Keywords: Vegetable Gardens, Farm Planning, Dynamic Programming, Climate Variability, Cameroon

\section{Introduction}

Cameroon champions the vegetable subsector in the Central African sub region both in output levels, export quantities and foreign exchange earnings [1]. The Institute of Agricultural Research for Development (IRAD) in 2010 estimated the annual value of vegetables and fruits in Cameroon to stand at 98.5 billion FCFA (US\$164 166 666.7). The potentials of this subsector therefore cannot be underestimated owing to growing demand for vegetables as a result of population pressures, increased integration of regional and sub-regional markets, and improved communication and infrastructural development. These recent trends have increased the level of both domestic agricultural trade and trade across regional blocks like the Economic and Monetary Community of Central African States (CEMAC) and the Economic Community of West African States (ECOWAS). Cameroon thus exports, formally and informally, fresh vegetables to neighboring countries like Nigeria, Central African Republic, Gabon, Equatorial 
Guinea, etc. and realizes a positive balance of trade with all these countries [2]. Amongst the agricultural products traded formally and informally across its borders, vegetable crops contribute a significant quota both in terms of exported quantity and foreign exchange earned, thus giving the vegetable subsector a strategic role to Cameroons' agricultural trade, food security, research and economic growth at large. Major vegetable crops exported to these countries include potato, tomatoes, cabbages, carrots, and watermelon.

Besides ensuring food self-sufficiency, the primary intention of vegetable farmers is to maximize farm profits subject to the numerous constraints like limited access to farm inputs, inadequate access to finance and land allocation challenges. These constraints are further compounded by an acute incidence of climate variability, seasonal price volatility and poor farm planning or timing. In such a difficult situation, the farmers hardly reap the optimum payoffs from their efforts. In trying to increase farm returns these farmers tend to adopt traditional procedures with trial and error, experience and instincts as guidelines to farm planning $[3,4]$. These traditional decision making techniques are generally unscientific and inefficient. Farmers often erroneously tend to increase the size of their farms with the hope for increased output [3]. This increase in farm size comes with an increase in variable input use and a corresponding increase in cost of production, but controversially, it does not guarantee an obvious increase in profits. A better way to address this problem could therefore be to adjust farm plans, prioritizing farm enterprises that will increase either output and farm profits without necessarily increasing the size of the farm-land cultivated or the amount of variable inputs used. Such an approach warrants proper adjustment of farm plans and cropping patterns (sequences), in response to the constantly fluctuating environmental and socioeconomic factors that determine the cost incurred and returns accrued from seasonal cultivation of vegetables.

At the farm scale, farmers have a particularly strong incentive to optimize their profit when resources are limited in quantity and quality. However, optimal usage of resources requires efficient techniques and decision making support. Mathematical programming has been widely used in farm management, especially in resource allocation studies. Farm planning is a process of working out in advance, an optimal plan, how many farm resources are going to be used in which enterprises for the whole farm over a specified period of time. An Optimal-farm plan, required for diversified farm enterprises, is an outline or summary of the type and volume of production to be carried out on the entire farm and the resources needed to do it.

Therefore, given the imperative to increase annual profitability of vegetable farming without a necessary increase in resource use, our principal research problem is to find out the most profitable vegetable enterprise choices a farmer should prioritise at each stage (production season), taking into consideration the prevailing economic and environmental trends so as to give an optimum annual cropping pattern (sequence) that yields maximum year-round profits. This study thus hypothesizes that, "the enterprise choices cultivated by a vegetable farmer per cropping season do not significantly influence his annual profits".

The remainder of this paper is structured as follows: section 2 describes the material and methods used for the study, section 3 presents the results of the study, while section 4 contains the conclusions and policy implications of the study.

\section{Materials and Methods}

\subsection{Description of Study Area}

This study is carried out in the Northwest Region of Cameroon. The region is located along the western highlands of the country, precisely between latitude $5^{0} 43$ "and $7^{0} 9$ ' $\mathrm{N}$ longitude $9^{0} 13$ " and $11^{\circ} 13$ "E in the Republic of Cameroon. The region shares boundary to the north and west with the Federal Republic of Nigeria, to the south with the South and Southwest Regions of Cameroon and to the east with the Adamawa Region of Cameroon. This region covers a total surface area of $17400 \mathrm{~km}^{2}$, characterized by the western highlands, with prominent land features like mountain ranges (e.g. Bamenda-Sabga mountain range), plateaus (e.g. the Bmenda-Oku-Kumbo-Njinikom high plateau) plains and valleys like the Ndop plains and the Menchum valleys respectively [5]. Located along the savanna region of the country, the Northwest falls within the Western Highlands Agro ecological zone. Similar to other regions of Cameroon, the Northwest presents a predominantly agrarian economy and other related activities being the main economic driving force, employing up to $80 \%$ of the population and accounting for their livelihoods and sustainability. Women constitute a majority of farmers in the Northwest, cultivating mostly food crops like maize, beans, cocoyam, yams, cassava, vegetables, etc. primarily for household consumption and the commercialization of surpluses to supplement family incomes.

\subsection{Conceptualization and Empirical Modeling}

Resource optimization involves processes and methods aimed at matching the available resources (human, natural, mechanical and financial) with the needs of the organization in order to achieve established goals. Making decisions on farm irrigation poses a huge challenge most especially to small-scale farmers. Pluriactive farmers must address the resource constraint in realizing their objectives by optimal planning. Optimization consists of achieving desired results within a set time frame, budget and with minimum usage of the resources themselves. The need to optimize resources is particularly evident when the organization's demands tend to saturate and/or exceed the resources currently available. Farm resource optimization theories make use of mathematical principles in choosing specific solutions from a set of alternatives in such a way as to best maximize a specific criterion. For example, this technology has been 
applied to optimize wheat crop rotation and to help reduce the uncertainty that is often associated with agriculture. This same theory also allows the analysis of patterns of growth and decline in modern farms.

Hassan et al. [6] reported that farmer's profits cannot be maximized without optimizing cropping patterns which ensure efficient utilization of farm resources. Above all, financial considerations drive most farmers' choices, as they have to ensure the economic viability of their investment. As such, farm management practices such as crop sequencing and rotation must ensure that the production remains sufficiently profitable if the farmer is expected to implement the practices regularly and consistently [7]. Besides economic benefits, a good choice of cropping sequence and its proper implementation presents an opportunity to reduce agriculture's pressure on the environment, either by either reducing its negative impacts or improving its positive impacts, or both [8].

A farm plan is the result of meticulous farm planning process. It is a statement of the enterprises to be undertaken over this time period. Performance analysis using arithmetic and functional analysis may reveal a particular enterprise to be highly profitable. However, there may be serious limits to expansion of the enterprise, imposed by physical, economic, social and environmental constraints. Thus maximization of overall profit of a farm business is governed by a number of constraints which need to be accommodated in planning a farm. Ibrahim and Omedesho [9] on their part studied the optimal farm plan for vegetable production in North Central Nigerian and concluded that the inclusion of environmental goals or considerations in farm planning by vegetable farmers was not necessarily antagonistic to their profit maximization goal. Their findings further disclosed that an expansion of land area under crop cultivation was critical to the improvement on the sustainability of vegetable farming in the study area. They therefore recommended policy formulation that would encourage land consolidation in farming communities. Adeoti [10] applied dynamic programming techniques to determine optimal farm plans under the Nigerian government's irrigation farm program. The study generated optimal plans in the dynamic decision environment of the farmers using a dynamic programming model. The optimal farm plan supports mixed farming but with sole okra as a predominant enterprise in this study area.

For our current study, the recursive dynamic programming model is specified within a cross-sectional framework. This model specifies three vegetable cropping seasons (MarchJune, July-October and November-February). These seasons appear as the various stages of the dynamic programming model. The model seeks to maximise annual profit (LHS) as a function of the seasonal profits accrued from the respective enterprise choices made by a farmer (RHS) at each stage (cropping season). This model as specified below is estimated for the three categories of vegetable farmers considered under this study as follows;

$$
\operatorname{Max} \mathrm{Z}_{\mathrm{ijz}}=\left\{\sum_{\mathrm{i}=1}^{\mathrm{k}}\left(\mathrm{P}_{\mathrm{i}} \mathrm{X}_{\mathrm{i}}-\mathrm{C}_{\mathrm{i}}\right)\right\}_{\mathrm{n}}+\left\{\sum_{\mathrm{j}=1}^{\mathrm{k}}\left(\mathrm{P}_{\mathrm{j}} \mathrm{X}_{\mathrm{j}}-\mathrm{C}_{\mathrm{j}}\right)\right\}_{\mathrm{n}+1}+
$$

$$
\left\{\sum_{\mathrm{z}=1}^{\mathrm{k}}\left(\mathrm{P}_{\mathrm{z}} \mathrm{X}_{\mathrm{z}}-\mathrm{C}_{\mathrm{z}}\right)\right\}_{\mathrm{n}+2}
$$

Subject to;

$$
\sum_{\mathrm{i}, \mathrm{j}, \mathrm{z}=1}^{\mathrm{k}}(\mathrm{di}+\mathrm{dj}+\mathrm{dz})
$$

Where

$\mathrm{Z}_{\mathrm{ijz}}=$ maximum annual profit

$\left\{\sum_{\mathrm{i}=1}^{\mathrm{k}}\left(\mathrm{P}_{\mathrm{i}} \mathrm{X}_{\mathrm{i}}-\mathrm{C}_{\mathrm{i}}\right)\right\}_{\mathrm{n}}=$ the profit realised during the first farming season (Mar-Jun)

$\left\{\sum_{\mathrm{j}=1}^{\mathrm{k}}\left(\mathrm{P}_{\mathrm{j}} \mathrm{X}_{\mathrm{j}}-\mathrm{C}_{\mathrm{j}}\right)\right\}_{\mathrm{n}+1}=$ profit realised during the second farming season (Jul-Oct)

$\left\{\sum_{\mathrm{z}=1}^{\mathrm{k}}\left(\mathrm{P}_{\mathrm{z}} \mathrm{X}_{\mathrm{z}}-\mathrm{C}_{\mathrm{z}}\right)\right\}_{\mathrm{n}+2}=$ profit realised during the third farming season (Nov-Feb)

$\mathrm{n}=$ stage 1 (first cropping season)

$\mathrm{n}+1=$ stage 2 (second cropping season)

$\mathrm{n}+2=$ stage 3 (third cropping season)

$\mathrm{P}_{\mathrm{ijz}}=$ market prices of respective enterprises in a particular season

$X_{\mathrm{ijz}}=$ various states (output of chosen vegetable enterprise per hectare)

$\mathrm{C}_{\mathrm{ijz}}=$ total cost per hectare of producing a chosen enterprise

$\mathrm{d}_{\mathrm{i}}, \mathrm{d}_{\mathrm{j}}, \mathrm{d}_{\mathrm{z}}=$ enterprise choices made cultivated by a farmer during the first, second and third cropping seasons respectively

$\mathrm{k}=$ number of vegetables enterprises cultivated at each stage.

\subsection{Nature and Source of Data}

A list of vegetable farming communities was generated with help of information from the Northwest Regional delegation of agriculture. Six vegetable farming communities were randomly selected from the sample area (Santa, Bafut, Oku, Bamungo, Bambui and Babanki). Twenty farmers were randomly selected and contacted in each of the six communities. The simple random sampling technique was employed so that each farmer in the study area had an equal chance of being selected. This therefore gave a sample size of 120 farmers, of which 33 were pluriactive part-time farmers. A questionnaire was used as the main instrument for data collection. Both open and closed ended questions were well structured and in simple language such that answers to these questions provided necessary data for the study. On this questionnaire, featured questions to capture the biography information and characteristics of farmers, their farm records and perception, challenges and prospective solutions to identified constraints. This was administered by personal discussion with the farmers. The data is then extracted from the questionnaire to compute costs of production, farm profits and returns of farm investments which were in turn factored into the empirical model.

The variables analyzed include total crop output, total cost of variable farm inputs, the total cost of fixed farm inputs, the cost of depreciation of farm tools and equipment, the profitability of the crop enterprise combinations and the 
return on investment of the crop enterprise combinations. Determination of Profitability was through the gross margin technique of farm budgeting analysis was used to access profitability of crop enterprises in the cropping system. The return-on-investment (ROI) by the farmers is used to assess the performance of the crop enterprise combinations in the entire cropping sequence. The part-time vegetable farmers included full-time staple food crop farmers who cultivate vegetables as a supplementary activity.

\section{Results and Discussion}

\subsection{Profile of Non-Specialised Vegetable Farmers}

It was observed in this study that; pluriactive farmers cultivate staple food crops like taro, yams, maize, cassava and other energy food crops as a major fulltime economic activity, while vegetables were only cultivated as supplementary or complementary enterprises. Although vegetable cultivation was largely subsistent and small in scale, it remainsa vital year-round activity and on average farmers cultivate over 16 different species of short seasoned vegetable crops annually. These include; Fruit vegetables (tomato, okra, garden egg, hot pepper, cucumber, watermelon, sweet pepper), Leafy vegetables (leaks, nightshade, cabbage, parsley, lettuce), Seed vegetables (maize, green beans), Tuber vegetables (Irish potato), Root vegetables (carrot) and Stem vegetables (celery). Despite the vitality of vegetable cultivation in this study area, vegetable farming is largely seen as a feminist activity, justifying whyover $72.5 \%$ of the farmers sampled in this study are female while only $27.5 \%$ are male. The findings also showed that $6 \%$ of the farmers contacted were below the age $25,18 \%$ were between $26-35$ years, $32 \%$ of the farmers were between the ages of $36-45$ while $44 \%$ were above the age of 45 . This therefore indicates that a majority of pluriactive vegetable farmers were aging with and average age of above 45 years. Over $6.7 \%$ of these farmers had no formal education, $59.2 \%$ had primary education, and $27 \%$ had secondary education while $11.7 \%$ had other diplomas. These statistics show very low standards of education in the study area and as such, adoption and incorporation of innovations may be less responsive amidstthis educational profile. Data from this work further indicates that over $20 \%$ of the farmers cultivate vegetables exclusively for household consumption. A second category of over $39.2 \%$ farmers cultivate vegetables primarily for commercial purposes while consuming. The last category of farmers $(40.2 \%)$ cultivated vegetables exclusively for commercial purposes with zero motivation for household consumption. Each of these farmers cultivated many individual farm lands simultaneously during one farming season. Apart from some $6.7 \%$ of the contacted farmers who carry out their farming activities on one piece of land, $13.3 \%$ of the farmers cultivated on 2 different pieces of land, $25 \%$ of them cultivated on 3 different pieces of land in one farming season. Averagely, $21.7 \%$ cultivated on 4 different pieces of land while $33.3 \%$ of the farmers cultivated on 5 and above different pieces of land. All these pieces of land were scattered at different geographic locations all over the village. However, farmers do rotate crop enterprises among these different lands in different seasons with the aim of meeting the water needs of the crop and to phase out pathogens and disease. This study further reveals that over $70 \%$ of the farmers cultivated a cumulated land size of less than 1 ha, $26.7 \%$ of farmers cultivated a total land size of between 1.1-2.0 ha, and 3.3\% of farmers cultivated a cumulative land area of above 2.0 ha. It was also observed that a significant quota of the farm labour is provided by the family. About $28.3 \%$ of the sampled farmers depended solely on family labour on their farms. Over $55 \%$ used a combination of family labour and hired labour, $8.3 \%$ of the farmers used solely hired labour, while another $8.3 \%$ practiced group farming (njangi farming) where in; on average, 4-6 farmers joint forces and work on each other's farm in a succession and on the bases of mutual benefits. Findings from this study declared that $56.7 \%$ of the sampled farmers used commercial motorbike services as the main means of transporting their farm produce from their farm to the market while $28.3 \%$ used taxi and other van services for the conveying of their produce to the market. However, $15 \%$ of the farmers used head portage in conveying their products to the market. These farmers sold their produce either at the farm gate to whole sellers, at local village markets, along major highways in the region or at the main food market in the Bamenda city. On average, a farmer spent 13655.09 FCFA (US\$ 22.8) per year on transportation of his produce to the market.

\subsection{Seasonal Profitability in Non-specialised Vegetable Farming}

Vegetable farming generally proved to be a very profitable activity capable of sustaining and improving the leaving standards of all the three categories of farmers under this study. However, findings reveal that vegetable farming is most rewarding in the study area during the dryer periods of the year. This validates the observations wherein, the third cropping season (Nov-Feb) presented the lowest levels of rainfall and the highest payoffs to vegetable cultivation (average profits of 1846845 FCFA (US\$ 3078.1) followed by the first cropping season (Mar-Jun, with average profits of 1615657 FCFA (US\$ 2692.8) which in turn witnessed lower rates of rainfall than the second cropping season (Jul-Oct). The second cropping season on its part reported the highest levels of rainfall and the lowest profits (1 442312 FCFA) (US\$ 2403.9) across all the three categories of farmers in the study area. The findings therefore suggest an inverse relationship between amountof rainfall and profitability of vegetable cropping in the study area. Profitability however varied greatly not only across seasons but also across farmer categories. This is presented on the table below. 
Table 1. Seasonal Profitability of Vegetable Farming.

\begin{tabular}{|c|c|c|c|c|c|c|c|c|c|}
\hline \multirow{2}{*}{ Combination } & \multicolumn{3}{|c|}{ Total cost/ha } & \multicolumn{3}{|l|}{ Profits/ha } & \multicolumn{3}{|c|}{ Return on Investment/ha } \\
\hline & Mar-Jun & Jul-Oct & Nov-Feb & Mar-Jun & Jul-Oct & Nov-Feb & Mar-Jun & Jul-Oct & Nov-Feb \\
\hline $\mathrm{C} 1$ & 1050113.5 & 1169837.4 & 1987459.1 & 1518070.2 & 1270582.6 & 1941779.1 & 143.8 & 106.8 & 97.3 \\
\hline $\mathrm{C} 2$ & 1024390.5 & 1034863.8 & 1817148.8 & 1456085.7 & 1410995.7 & 1752748.8 & 142.2 & 137.3 & 96.3 \\
\hline $\mathrm{C} 3$ & 1062735.2 & & 1792497.1 & 1532502.9 & & 1752114.3 & 144.4 & & 96.3 \\
\hline $\mathrm{C} 4$ & 1295360 & & & 1903840 & & & 147 & & \\
\hline $\mathrm{C} 5$ & 892457.1 & 1042757.1 & 1319314.3 & 1254685.7 & 1104385.7 & 1252114.3 & 140.6 & 105.9 & 96.3 \\
\hline C6 & 1105866.7 & 1292533.3 & 170586.7 & 1560800 & 1374133.3 & 1627466.7 & 141.1 & 106.3 & 95.4 \\
\hline
\end{tabular}

Fruit vegetables $(\mathrm{C} 1)=$ Tomato-Okra-Garden Egg-Hot pepper-cucumber-watermelon-sweet pepper, Leafy vegetables $(\mathrm{C} 2)=$ Leaks-Huckleberry-cabbageparsley-lettuce, Seed vegetables $(\mathrm{C} 3)=$ Maize-green beans, Tuber vegetables $(\mathrm{C} 4)=$ Irish potato, Root vegetables $(\mathrm{C} 5)=$ Carrot, Stem vegetables $(\mathrm{C} 6)=$ Celery

\subsection{Proposed Optimum Cropping Sequence}

Three optimal cropping patterns (cropping sequences) were identified subject to the analysis of the survey data. The optimal annual cropping sequences (from March-February) for the various vegetable enterprises in the study area that maximize annual farm returns at minimum cost were obtained through the application of mathematical algorithm and dynamic programming techniques. Based on the results of the dynamic programming model for this category of farmers, it was observed that the tuber vegetable enterprise combination (C4) was the most profitable (1 $903 \quad 840$ FCFA/ha) (US\$ 3173.1/ha) during the first cropping season of the year (Mar-Jun) thus qualifying for the optimal cropping sequence at this stage. The leafy vegetable crop enterprise mix (C2) on its parts was the most profitable (141 099.7 FCFA/ha) (US\$ 235.2/ha) during the second cropping season and thus qualified for the optimal cropping sequence at the second stage (Jul-Oct) while the fruit vegetable enterprise mix proved most profitable (1 $941779.1 \mathrm{FCFA} / \mathrm{ha}$ ) (US\$ 3236.3/ha) during the third season and appeared at the last stage (Nov-Feb). This optimal cropping sequence yields an average annual profit of 5256614.8 FCFA (US\$ 8761.0), as summarized in figure 1.

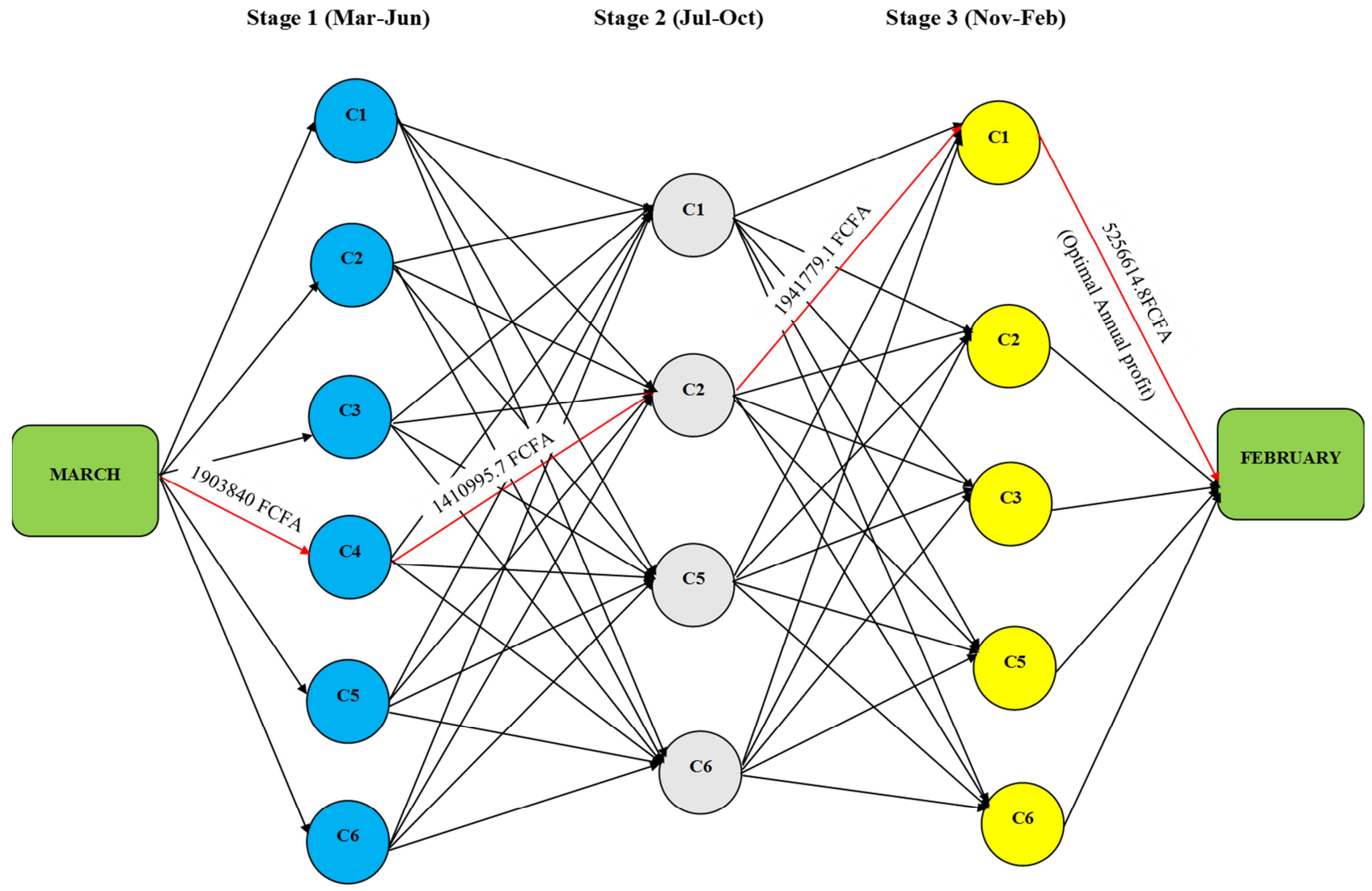

Figure 1. Optimal Cropping Sequence of Vegetable Enterprises for part-time farmers.

Fruit vegetables $(\mathrm{C} 1)=$ Tomato-Okra-Garden Egg-Hot pepper-cucumber-watermelon-sweet pepper, Leafy vegetables $(\mathrm{C} 2)=\mathrm{Leaks}-\mathrm{Huckleberry-cabbage-}$ parsley-lettuce, Seed vegetables $(\mathrm{C} 3)=$ Maize-green beans, Tuber vegetables $(\mathrm{C} 4)=$ Irish potato, Root vegetables $(\mathrm{C} 5)=\mathrm{Carrot}$, Stem vegetables $(\mathrm{C} 6)=\mathrm{Celery}$ (Source: survey data 2017) 
The findings reveal that vegetable farming is a very profitable activity capable of sustaining and improving the living conditions of farmers. One of the most striking facts uncovered by this study is that, in the study area, vegetable farming is most rewarding during the dryer periods of the year. This validates the observations wherein, the third cropping season (Nov-Feb) presented the lowest levels of rainfall and the highest payoffs to vegetable cultivation followed by the first cropping season (Mar-Jun) which in turn witnessed lower rates of rainfall than the second cropping (Jul-Oct). The second cropping season on its part reported the highest levels of rainfall and the lowest profits across all the three categories of farmers in the study area. This observation suggests a possible negative correlation between rainfall and profitability of vegetable cultivation in the study area.

A further examination of the profitability of the respective enterprise combinations justify that the fruit vegetables on average present the highest profit margins under irrigation (during the third cultivation season) for all three categories of farmers in the study area. This backs their appearance on the optimal cropping sequence during the third cropping season (Nov-Feb) which is characterised by total dryness. However, these high profits can only be accrued at the mercy of increased capital investment due to high irrigation cost factored into the production cost. All farming activities during this period are entirely under irrigated conditions. In addition, most fruit vegetables (e.g. watermelon, cucumber, etc.) record their highest market demands during the dry periods of the year and their prices are seen to be highly responsive to market demand. It is therefore normal for these vegetable species to command their highest market prices during this period, thus generating maximum rewards to the farmers at this stage.

\section{Conclusion}

Given the fundamental relevance of pluriactive farming to the livelihoods of rural population in particular and the economy of Cameroon at large, enhancing its productivity will be a right step towards the pursuit of sustainable food and nutritional security. Efficient farm planning and resource allocation as recommended by sound agricultural development research is therefore a necessity. This study is thus considered timely and its recommendations provide options for policy intervention in a bid to curb food and nutritional insecurity and reduction of the incidence of poverty among the rural population of Cameroon.

\section{References}

[1] Achancho, V. (2013). Revue et analyse des stratégiesnationalesd'investissements et des politiquesagricoles en Afrique du Centre: Cas du Cameroun. In A. Elbehri (Ed.), Reconstruire le potentielalimentaire de l'Afrique de l'Ouest: FAO/FIDA.

[2] Nkendah, R. (2013). Estimating the Informal Cross-border Trade of Agricultural and Horticultural Commodities between Cameroon and its CEMAC Neighbours. Journal of food policy, 41, 133-144.

[3] Alsheikh, S. M., \& Ahmed, A. M. (2002). Development of Mixed Farming System in a Newly Reclaimed Area in Egypt. Session No. LMP3.12. Abstract No. 107.

[4] Shu, G., Minkoa, J. R. N., and Molua, E. L. (2018). Cropping Sequence in Micro-scale Vegetables in the Northwest Region of Cameroon. Americanc Journal of Rural Development, VOL $6(2), 29-37$.

[5] BCC (2017). Bamenda City Profile. Bamenda City Council, Bamenda, Cameron. Retried at; www.bamendacity.com.

[6] Hassan, I., Ahmad, P., Akhter, M. and Aslam, M. (2005). Use of Linear Programming Model to Determine the Optimum Cropping Pattern: A case Study of Punjab Journal of Economic and Social Studies, 44, 117-136.

[7] European Union, bio intelligence service. (2010). Environmental Impact of Different Crop Rotations in the European Nation. Conference paper presented at Sustainability planning (contract No. 07.0307/2009). Retrieved from http//:ec.eu.europa.eu.

[8] Molua, E. L. (2008). Turning up the heat on African agriculture: The impact of climate change on Cameroon's agriculture. AfJARE 2 (1), 220-238.

[9] Ibrahim, H. and Omotesho, A. O. (2009). An assessment of the sustainability of vegetable production under Fadama in the northern guinea savannah zone of Nigeria. Journal of Economic and Social Studies, 44, 117-136.

[10] Adeoti, A. I. (2001). EconomicAnalysis of Irrigated and Rain fed Production Systems in Kwara State. Nigeria. PhD Thesis in the Department of Agricultural Economics, University of Ibadan, Ibadan, Nigeria. 